\section{Commentary: Wrapping the Ross could prevent its loss!}

\author{
Kanika Kalra, MD, and Edward P. Chen, MD $^{\mathrm{b}}$
}

The Ross procedure is a complex procedure offering an attractive option for young patients with aortic valve degeneration wishing to avoid lifetime anticoagulation. Despite a proven lower thromboembolism risk and better quality of life compared with other prostheses, its adoption in patients with a bicuspid aortic valve (BAV) has been limited to a few centers and has not been completely endorsed in the American Heart Association and Society for Thoracic Surgeons guidelines. ${ }^{1,2}$ Previous studies have demonstrated favorable outcomes of the Ross procedure in the setting of $\mathrm{BAV}^{3,4}$ suggesting that it is a feasible option for BAV degeneration.

We commend the authors for their outcomes comparing the pulmonary autograft inclusion technique (wrapped using a straight vascular conduit) and the unsupported autograft root replacement technique (unwrapped) in BAV patients. ${ }^{5}$ Ten-year survival was excellent in both groups; however, autograft valve failure was higher in the unwrapped group compared with the wrapped group $(35.2 \%$ vs $5.2 \%$ ). The cumulative incidence of autograft reintervention at 10 years was significantly higher in the unwrapped group $(26.4 \%$ vs $4 \%)$, and no aortic root intervention was needed in the wrapped group, as opposed to 16 out of 25 $(64 \%)$ patients requiring aortic root replacement in the unwrapped group. At a median follow-up of 4.3 years, the addition of wrapping clearly seems to support the autograft and is protective against subsequent dilation.

The Ross procedure was originally described using a subcoronary implantation of a pulmonary autograft. ${ }^{6}$ This technique would prove potentially challenging in cases of

\footnotetext{
From the a Division of Cardiothoracic Surgery, Department of Surgery, Emory University School of Medicine, Atlanta, Ga; and ${ }^{\mathrm{b}}$ Division of Cardiothoracic Surgery, Duke University School of Medicine, Durham, NC.

Disclosures: The authors reported no conflicts of interest.

The Journal policy requires editors and reviewers to disclose conflicts of interest and to decline handling or reviewing manuscripts for which they may have a conflict of interest. The editors and reviewers of this article have no conflicts of interest.

Received for publication Feb 24, 2021; revisions received Feb 24, 2021; accepted for publication Feb 25, 2021; available ahead of print March 4, 2021.

Address for reprints: Edward P. Chen, MD, Division of Cardiothoracic Surgery, Duke University Medical Center, 2301 Erwin Rd, 8660 HAFS Building, Durham, NC 27710 (E-mail: edward.p.chen@duke.edu).

J Thorac Cardiovasc Surg 2023;165:56-7

$0022-5223 / \$ 36.00$

Copyright (c) 2021 by The American Association for Thoracic Surgery

https://doi.org/10.1016/j.jtcvs.2021.02.091
}

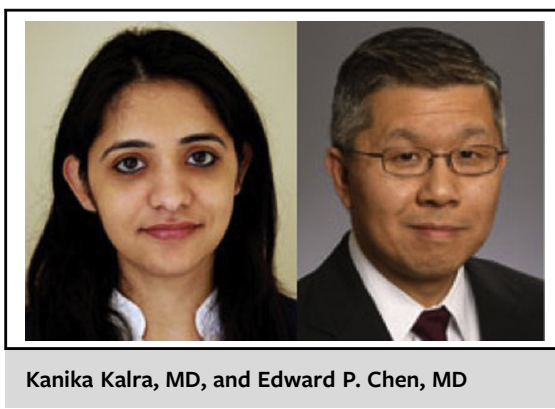

CENTRAL MESSAGE

Autograft reinforcement using a straight vascular conduit during

the Ross procedure could prevent future dilation and the need

for reintervention in patients

with a bicuspid aortic valve.

significant aortic-pulmonary root mismatch. Owing to its occurrence in BAV cases where major dissymmetry can occur between aortic cusps, many groups now perform a full root replacement and use reinforcement strategies to prevent autograft dilation in an unsupported root.

This study both underscores the need for autograft reinforcement for improving durability of the Ross procedure and validates the group's approach of using a vascular conduit as a support material as a viable technique. Several strategies have been described for autograft support including Dacron strips at the annulus and sinotubular junction, pericardium, a Valsalva graft, a Gore-Tex graft or a native aortic root wrap. Using these methods, many previous studies have demonstrated a durability advantage for a supported autograft root over an unsupported root with good midterm results, ${ }^{7,8}$ including the German-Dutch Registry data use of autograft inclusion technique in BAV patients. ${ }^{9}$ The choice of technique for autograft reinforcement is a matter of surgical judgment; however, prosthetic material clearly provides a rigid encasement around the autograft and appears to be reasonable in patients with a BAV given the potentially greater risk of future dilation. Annular and sinotubular junction reinforcement alone does not appear to prevent the dilation of neosinuses that occurs in the BAV population. ${ }^{4}$

Data focusing on BAV patients is still sparse, and thus the current study makes a valuable addition. We support the addition of the reinforced Ross procedure in the surgical armamentarium for young patients with BAV and 
acknowledge that long-term outcome data will be needed to bring about potential changes to practice guidelines, given the complexity of the Ross procedure.

\section{References}

1. Otto CM, Nishimura RA, Bonow RO, Carabello BA, Erwin JP III, Gentile F, et al. 2020 ACC/AHA guideline for the management of patients with valvular heart disease: a report of the American College of Cardiology/American Heart Association Joint Committee on clinical practice guidelines. Circulation. 2021; 143:e72-227.

2. Svensson LG, Adams DH, Bonow RO, Kouchoukos NT, Miller DC, O'Gara PT, et al. Aortic valve and ascending aorta guidelines for management and quality measures. Ann Thorac Surg. 2013;95(6 Suppl):S1-66.

3. Poh CL, Burratto E, Larobina M, Wynne R, O'Keefe M, Goldblatt J, et al. The Ross procedure in adults presenting with bicuspid aortic valve and pure aortic regurgitation: $85 \%$ freedom from reoperation at 20 years. Eur J Cardiothorac Surg. 2018;54:420-6.
4. Hanke T, Charitos EI, Stierle U, Robinson DR, Hemmer W, Moritz A, et al. The Ross operation: a feasible and safe option in the setting of a bicuspid aortic valve? Eur J Cardiothorac Surg. 2010;38:333-9.

5. Starnes VA, Elsayed RS, Cohen RG, Olds AP, Bojki MM, Mack WJ, et al. Longterm outcomes with the pulmonary autograft inclusion technique in adults with bicuspid aortic valves undergoing the Ross procedure. J Thorac Cardiovasc Surg. 2023;165:43-52.e2.

6. Sievers HH, Hanke T, Stierle U, Bechtel MF, Graf B, Robinson DR, et al. A critical reappraisal of the Ross operation: renaissance of the subcoronary implantation technique? Circulation. 2006;114(1 Suppl):I504-11.

7. Ashfaq A, Leeds H, Shen I, Muralidaran A. Reinforced Ross operation and intermediate- to long-term follow-up. J Thorac Dis. 2020;12:1219-23.

8. Juthier F, Banfi C, Vincentelli A, Ennezat PV, Le Tourneau T, Pinçon C, et al Modified Ross operation with reinforcement of the pulmonary autograft: sixyear results. J Thorac Cardiovasc Surg. 2010;139:1420-3.

9. Charitos EI, Hanke T, Stierle U, Robinson DR, Bogers AJJC, Hemmer W, et al Autograft reinforcement to preserve autograft function after the Ross procedure: a report from the German-Dutch Ross registry. Circulation. 2009;120(11 Suppl):S146-54. 